\title{
PROFIL GELATINISASI TEPUNG SORGUM PUTIH TERMODIFIKASI $\alpha$-AMILASE
}

\author{
[Pasting Properties of White Sorghum Flour Modified by a-Amylase]
}

\author{
Endah Wulandari*, Een Sukarminah, Efri Mardawati, dan Hanni Listia Furi \\ Departemen Teknologi Industri Pangan, Fakultas Teknologi Industri Pertanian, Universitas Padjadjaran, Bandung
}

Diterima 22 Maret 2019 / Disetujui 18 November 2019

\begin{abstract}
Sorghum is potential to be developed into flour based products due its high starch content (around $80.42 \%)$. However, native sorghum flour is unstable during cooking, has low viscosity, and limited swelling power resulting in limited use in the industry. Starch in sorghum flour requires long cooking time and high cooking temperature, therefore modifications is needed to improve the properties of the sorghum starch. Enzymatic modification using $\alpha$-amylase at (0,200, 400, and 600 units/g) was selected. The results showed that modification using a-amylase of 200 units $/ g$ flour produced better characteristics of modified sorghum flour. The $\alpha$-amylase modified flour has A type pattern of amylography, gelatinization temperature of $78.77^{\circ} \mathrm{C}$, peak viscosity of $1266.67 \mathrm{BU}$, starch content of $48.41 \%$, amylose content of $15.77 \%$, and amylopectin content of $32.64 \%$. The characteristics make the flour suitable for use in the manufacture of extrusion products.
\end{abstract}

Keywords: sorghum flour, $\alpha$-amylase, profile of gelatinization

\begin{abstract}
ABSTRAK
Sorgum berpotensi untuk dikem bangkan menjadi produk berbasis tepung karena memiliki kandung an pati cukup tinggi sekitar $80,42 \%$, namun sifat alami tepung sorgum yang tidak stabil selama pemasakan, nilai viskositas yang rendah, serta swelling power yang terbatas menyebabkan tepung sorgum terbatas penggunaannya dalam industri. Tingginya pati dalam tepung sorgum memerlukan waktu pemasakan yang lama dan suhu pemasakan yang tinggi, oleh karena itu perlu dilakukan modifikasi untuk memperbaiki sifat pati tepung sorgum. Dalam penelitian ini, modifikasi dilakukan secara enzimatis menggunakan enzim $\alpha$-amilase pada konsentrasi $(0,200,400$, dan 600 unit/g). Hasil penelitian menunjukkan modifikasi dengan konsentrasi enzim $\alpha$-amilase sebesar 200 unit/g tepung menghasilkan tepung sorgum termodifikasi $\alpha$ amilase dengan karakteristik yang lebih baik dibanding tepung sorgum alami. Sifat tepung sorgum termodifikasi mempunyai pola amilografi tipe A dengan suhu gelatinisasi $78,77^{\circ} \mathrm{C}$ dan viskositas puncak 1266,67 BU dengan kadar pati 48,41\%, kadar amilosa 15,77\%, dan kadar amilopektin 32,64\%, sehingga cocok untuk digunakan pada pembuatan produk ekstrusi.
\end{abstract}

Kata kunci: tepung sorgum, $\alpha$-amilase, profil gelatinisasi

\section{PENDAHULUAN}

Sorgum mempunyai kandungan vitamin dan mineral yang lebih tinggi dibandingkan dengan gandum, yaitu kandungan tiamin, riboflavin, niasin, kalsium, zat besi sorgum adalah 0,$38 ; 0,15 ; 4,30 ; 25$; 5,40 , sedangkan pada gandum yaitu 0,$41 ; 0,10$; 5,10; 30; 3,50 (Mokrane et al., 2010). Sorgum cocok

*Penulis Korespondensi:

Email: endah.wulandari@unpad.ac.id dikembangkan menjadi produk tepung karena memiliki kandungan pati sekitar $80,42 \%$ (Suarni, 2016). Biji sorgum dapat diolah menjadi tepung sorgum dengan kandungan pati cukup tinggi yaitu sekitar $80,42 \%$ (Elkhalifa dan Bernhardt, 2010). Pati dalam tepung sorgum membutuhkan waktu pemasakan yang tidak sebentar dan membentuk pasta pati yang tidak lunak dan keruh (berwarna abu-abu), sehingga modifikasi pati diperlukan untuk menghasilkan pati sorgum dengan sifat yang diinginkan (Yan dan Zhengbiao, 2010). 
Menurut Neelam et al. (2012), modifikasi dapat dilakukan dengan berbagai metode, baik secara fisik, kimia, enzimatis, maupun kombinasi. Setiap metode modifikasi tersebut menghasilkan pati termodifikasi dengan sifat yang berbeda-beda. Pati yang dihasilkan dari modifikasi menggunakan metode enzimatis memiliki viskositas yang stabil pada suhu ting gi dan rendah, berat molekul yang rendah, dan pembentukan gel yang baik (Kaur et al., 2012).

Modifikasi enzimatis dilakukan dengan mereaksikan pati sorgum yang telah dikondisikan dengan enzim amilase, melalui hidrolisis pati menjadi gulagula sederhana dengan memutus ikatan glikosidik di dalam struktur pati. Pati pada tepung sorgum kultivar lokal Bandung yang mengalami perubahan struktur molekul akan berpengaruh pada sifat fisikokimia, sifat fungsional, dan sifat amilografinya (Yan dan Zhengbiao, 2010). Penelitian ini bertujuan untuk mengkaji profil gelatinisasi tepung sorgum termodifikasi enzimatis.

\section{BAHAN DAN METODE}

\section{Bahan}

Bahan yang digunakan adalah tepung sorgum putih (80 mesh) kultivar lokal Bandung dari desa Cimanggu, kecamatan Pameungpeuk, Banjaran Kabupaten Bandung. Bahan lainnya yaitu enzim $\alpha$ amilase (Liquozyme Supra ${ }^{\circledR}$ ) yang bersifat termostabil, larutan penyangga (buffer) fosfat $0,02 \mathrm{M} \mathrm{pH}$ 6,9 .

\section{Preparasi sampel}

Tepung sorgum ditimbang sebanyak $12,5 \mathrm{~g}$ lalu ditambahkan $50 \mathrm{~mL}$ larutan buffer fosfat $0,02 \mathrm{M} \mathrm{pH}$ 6,9 dan enzim a-amilase (Liquozyme Supra ${ }^{\circledR}$ ) dengan konsentrasi yang telah ditentukan, yaitu 0 , 200, 400, dan 600 unit/g tepung sorgum. Inkubasi dilakukan pada suhu $55^{\circ} \mathrm{C}$ selama 20 jam dengan pengadukan kontinyu $120 \mathrm{rpm}$. Pengadukan dilakukan untuk meningkatkan reaksi hidrolisis enzimatis yang berlangsung selama inkubasi. Hasil hidrolisis disentrifugasi dengan kecepatan 3800 rpm selama 15 menit dengan alat sentrifugal (Z 306 Hermle, Germany), selanjutnya dilakukan pemisahan antara supernatan dan endapan. Endapan tepung sorgum disuspensikan ke dalam $50 \mathrm{~mL}$ akuades dan disentrifugasi kembali. Pengeringan menggunakan alat pengering kabinet (Memmert, Germany) untuk menguapkan sisa air atau larutan buffer yang terdapat di dalam endapan tepung sorgum pada suhu $\pm 40^{\circ} \mathrm{C}$ selama \pm 48 jam, proses dianggap selesai apabila tepung sorgum hasil modifikasi tidak menempel di permukaan wadah pengeringan. Pengayakan dilakukan untuk menyeragamkan ukuran tepung. Tepung sor- gum diayak menggunakan ayakan 80 mesh dan dikemas dalam kemasan kantung plastik.

\section{Analisis sifat amilografi menggunakan rapid vis- co analyzer (RVA)}

Berat sampel dan akuades yang digunakan dihitung dengan rumus:

$S_{1}=\frac{S_{0}\left(100-\mu_{0}\right)}{\left(100-\mu_{1}\right)}$

$W_{1}=W_{0}+\left(S_{0}-S_{1}\right)$

dimana, $S_{0}=$ standar berat sampel $(3,5 \mathrm{~g}) ; \mathrm{S}_{1}=$ berat sampel $(\mathrm{g}) ; \mu_{0}=$ standar kadar air $(11 \%) ; \mu_{1}=$ kadar air sampel (\%); $\mathrm{W}_{0}=$ standar berat air (25 g); dan $\mathrm{W}_{1}$ $=$ berat air untuk sampel $(\mathrm{g})$.

Sampel ditambah akuades lalu dimasukkan ke dalam bow amylograph yang terdapat pada alat RVA (Starch Master 2 Perten, Australia). Sampel dipanaskan hingga suhunya mencapai $50^{\circ} \mathrm{C}$, dilanjutkan hingga mencapai $95^{\circ} \mathrm{C}$ dan dipertahankan selama 5 menit. Sampel didinginkan hingga mencapai $50^{\circ} \mathrm{C}$ dan dipertahankan selama 4 menit. Profil gelatinisasi pasta seperti suhu gelatinisasi, viskositas puncak, waktu untuk mencapai viskositas puncak, viskositas pasta panas, pasta dingin, break-down, dan setback langsung diperoleh dan dihitung dari kurva gelatinisasi melalui perangkat lunak RVA.

\section{Analisis derajat putih menggunakan Kett Electric Laboratory C-100-3 Whitenessmeter}

Alat dikalibrasi terlebih dahulu menggunakan standar derajat putih, yaitu $\mathrm{BaSO}_{4}$ yang memiliki derajat putih $100 \%$. Setelah dikalibrasi, sampel dimasukkan ke dalam wadah sampel sampai benarbenar padat lalu ditutup. Wadah yang telah berisi sampel dimasukkan ke dalam tempat pengukuran lalu nilai derajat putih (A) akan muncul pada layar. Derajat putih tepung dapat dihitung dengan rumus berikut:

$\mathrm{DP}(\%)=\frac{\mathrm{A}}{\text { nilai standar } \mathrm{BaSO}_{4}} \times 100 \%$

dimana, $\mathrm{DP}=$ derajat putih tepung $(\%), \mathrm{A}=$ nilai yang terbaca pada alat.

\section{Pengamatan bentuk dan ukuran granula pati menggunakan scanning electron microscope (SEM)}

Tepung Sorgum alami dan yang termodifikasi enzim a-amilase, ditaburkan (sprinkling) pada wadah sampel sampai tersebar merata lalu ditutup kemudian diamati dengan SEM. 
Analisis fraksi pati sorgum (Kadar amilosa dan amilopektin)(Atma, 2018)

Sebanyak $100 \mathrm{mg}$ sampel dimasukkan ke dalam tabung reaksi dan ditambahkan $1 \mathrm{~mL}$ etanol $95 \%$ dan $9 \mathrm{~mL} \mathrm{NaOH} 1 \mathrm{~N}$. Sampel kemudian dipanaskan selama 10 menit untuk membentuk gel. Setelah didinginkan, gel dimasukkan ke dalam labu ukur $100 \mathrm{~mL}$ dan ditepatkan hingga tanda batas menggunakan akuades. Sebanyak $5 \mathrm{~mL}$ larutan tersebut dimasukkan ke dalam labu ukur $100 \mathrm{~mL}$, lalu ditambahkan $1 \mathrm{~mL}$ asam asetat $1 \mathrm{~N}, 2 \mathrm{~mL}$ larutan iodium, dan akuades hingga tanda batas. Setelah didiamkan selama 20 menit, sampel diukur absorbansinya pada panjang gelombang $625 \mathrm{~nm}$. Kadar amilosa ditentukan dengan cara nilai y pada persamaan linear kurva standar amilosa sehingga diperoleh nilai $x$, yaitu jumlah amilosa sampel. Kadar amilopektin ditentukan sebagai selisih antara kadar pati dengan kadar amilosa.

\section{HASIL DAN PEMBAHASAN}

\section{Profil gelatinisasi}

Granula pati membengkak dan bersifat irreversible disebabkan oleh proses pemanasan yang kontinyu (Deka dan Sit, 2016). Kemampuan menarik air molekul pati penyusun tepung lebih lemah dibandingkan gerakan molekul air yang panas sehingga air mudah masuk ke dalam granula (Kulamarva et al., 2009). Sifat amilografi diperlukan untuk identifikasi perubahan respon amilografi akibat perbedaan variabel bahan atau proses, pendugaan sifat pati selama pengolahan, dan identifikasi data awal untuk keperluan set-up peralatan pengolahan pati dan tepung (Karmakar et al., 2014). Kurva profil gelatinisasi tepung sorgum termodifikasi enzim $\alpha$-amilase terdapat pada Gambar 1.

Kurva profil gelatinisasi (Gambar 1), memperlihatkan bahwa tepung sorgum termodifikasi enzimatis memiliki pola viskositas tipe $A$ yang ditandai oleh puncak kurva yang tajam, menunjukkan pati memiliki kapasitas pengembangan pati yang tinggi. Hal tersebut ditunjukkan oleh tingginya viskositas puncak yang diikuti oleh penurunan viskositas yang cepat selama pemasakan menyebabkan granula pati mengembang secara berlebihan ketika dimasak dalam air dan ikatan dalam granula pati menjadi lemah sehingga pati mudah pecah. Tepung sorgum alami memiliki pola viskositas tipe $B$ yang ditunjukkan oleh penurunan kurva yang kurang tajam. Tepung tipe $B$ memiliki kapasitas pengembangan pati sedang, ditandai dengan viskositas puncak yang lebih rendah dibanding tipe A dan mengalami penurunan viskositas yang tidak terlalu besar selama pemasakan. Hal ini disebabkan oleh granula pati yang tidak mengembang secara berlebihan sehingga pati tidak mudah pecah. Medikasari et al. (2005) menyatakan bahwa perbedaan kadar amilosa tepung dapat menyebabkan perbedaan sifat fungsional dan pola amilografinya. Hasil pengujian profil gelatinisasi tepung sorgum termodifikasi enzimatis ditunjukkan pada Tabel 1.

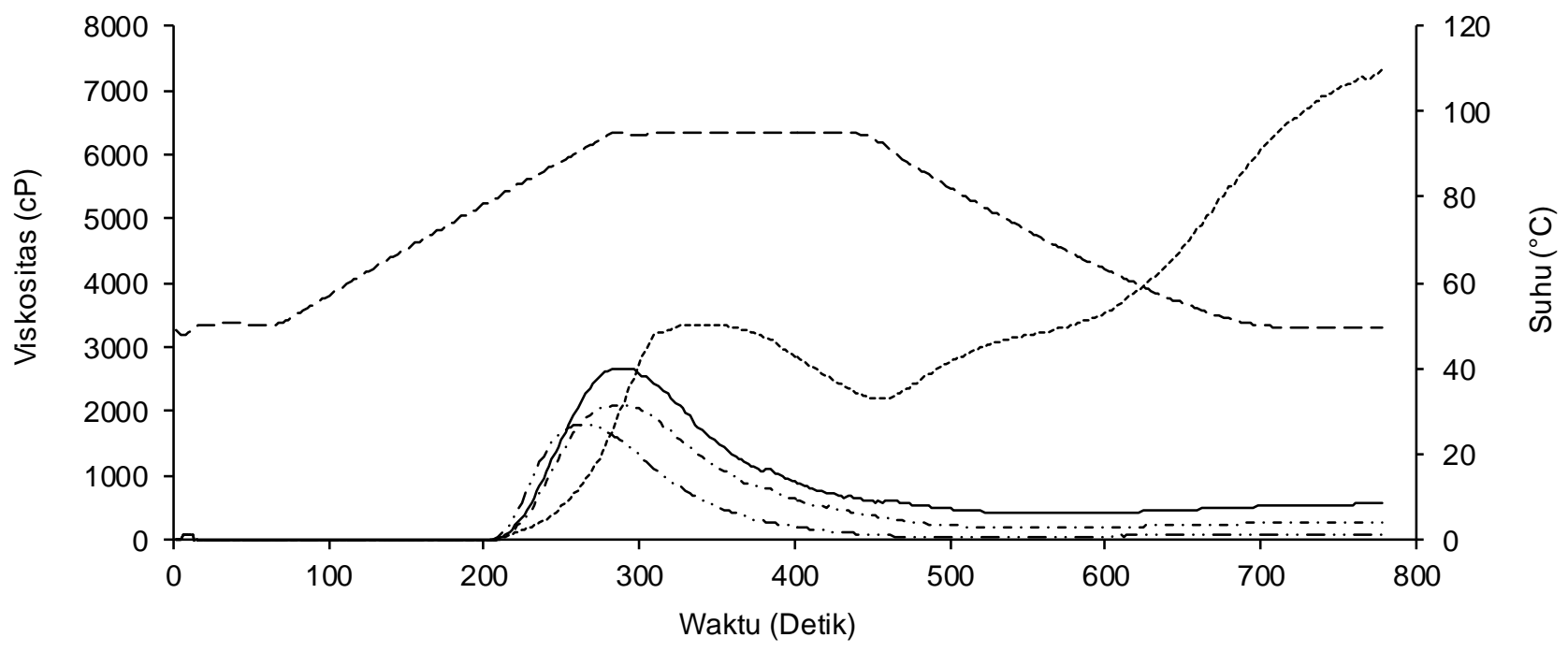

Alami 200 unit/g -....400 unit/g - - - $\quad 600$ unit/g - - - Suhu

Gambar 1. Kurva profil gelatinisasi tepung sorgum termodifikasi enzimatis 
Tabel 1. Sifat amilografi tepung sorgum termodifikasi enzimatis

\begin{tabular}{lcccccc}
\hline \multicolumn{1}{c}{ Perlakuan } & $\mathrm{SG}\left({ }^{\circ} \mathrm{C}\right)$ & VP $(\mathrm{BU})$ & VPP $(\mathrm{cP})$ & $\begin{array}{c}\text { Breakdown } \\
(\mathrm{cP})\end{array}$ & $\begin{array}{c}\text { VPD } \\
(\mathrm{cP})\end{array}$ & $\begin{array}{c}\text { Setback } \\
(\mathrm{cP})\end{array}$ \\
\hline Tepung sorgum alami & $78,20 \pm$ & $1594,29 \pm$ & $2184 \pm 41,53$ & $1164 \pm 154,55$ & $7321 \pm$ & $5137 \pm$ \\
Tepung sorgum termodifikasi & $78,77 \pm$ & $1266,67 \pm$ & $406 \pm 55,45$ & $2254 \pm 33,81$ & $554 \pm 57,79$ & $148 \pm$ \\
enzim $\alpha$-amilase 200 unit/g & 0,77 & 48,50 & & & 74,47 \\
Tepung sorgum termodifikasi & $78,74 \pm$ & $998,57 \pm$ & $179 \pm 55,85$ & $1918 \pm 150,38$ & $268 \pm$ & $89 \pm$ \\
enzim $\alpha$-amilase 400 unit/g & 0,66 & 186,08 & & & 108,98 & 101,93 \\
Tepung sorgum termodifikasi & $77,48 \pm$ & $856,19 \pm$ & $35 \pm 27,47$ & $1763 \pm 130,40$ & $82 \pm 165,85$ & $47 \pm$ \\
enzim $\alpha$-amilase 600 unit/g & 0,88 & 192,69 & & & & 39,09
\end{tabular}

Keterangan: $\mathrm{SG}=$ Suhu awal gelatinisasi; VP= Viskositas puncak; VPP= Viskositas pasta panas; VPD= Viskositas pasta dingin

Tabel 1 memperlihatkan bahwa semua parameter profil gelatinisasi tepung sorgum termodifikasi enzimatis mengalami penurunan seiring meningkatnya konsentrasi enzim. Hal ini berkaitan dengan aktivitas $\alpha$-amilase yang memutus ikatan $\alpha$-1,4-glikosidik sehingga menyebabkan melemahnya struktur granula pati dan cenderung mengalami disintegrasi. Semakin tinggi konsentrasi $\alpha$-amilase yang digunakan maka laju reaksi hidrolisis akan meningkat, sehingga semakin banyak ikatan $\alpha$-1,4-glikosidik yang terputus dan struktur pati akan semakin melemah. Melemahnya struktur pati menyebabkan kemampuan pati untuk menyerap air dan mengembang semakin berkurang sehingga terjadi penurunan suhu gelatinisasi dan viskositas pasta, dengan demikian semakin tinggi konsentrasi enzim $\alpha$-amilase yang digunakan, maka suhu gelatinisasi dan viskositas pasta tepung sorgum termodifikasi enzimatis ini semakin menurun.

Ukuran granula tepung sorgum termodifikasi enzimatis semakin kecil seiring dengan meningkatnya konsentrasi enzim (Tabel 2). Hidrolisis pati dengan enzim menyebabkan ukuran molekul menjadi semakin kecil, sehingga dimungkinkan gelatinisasi terjadi secara serempak sehingga proses gelatinisasi menjadi lebih cepat dan sebagai imbasnya suhu gelatinisasi tepung menjadi turun (Kulamarva et al., 2009). Granula pati juga pada memengaruhi perubahan suhu gelatinisasi granula pati yang mempunyai ukuran lebih besar mempunyai ketahanan terhadap perlakuan panas dan air yang lebih tinggi dibandingkan dengan granula pati yang mempunyai ukuran granula yang kecil (Murtiningrum et al., 2012), dengan demikian, semakin tinggi konsentrasi enzim $\alpha$-amilase yang digunakan maka semakin kecil ukuran granula pati sehingga suhu gelatinisasi semakin rendah pula. Berikut adalah pengamatan terhadap sifat fisik tepung sorgum termodifikasi (Tabel 2).

Pengamatan yang tertera pada Tabel 2, dapat diketahui bahwa granula tepung sorgum termodifikasi enzimatis berukuran lebih kecil dibanding granula tepung sorgum alami. Tepung sorgum termodifikasi enzimatis memiliki ukuran granula berkisar antara 14,50-16,88 $\mu \mathrm{m}$ dengan ukuran granula te- pung sorgum alami sebesar 17,36 $\mu \mathrm{m}$. Hal ini disebabkan oleh aktivitas enzim $\alpha$-amilase yang me-

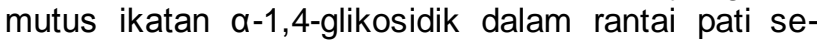
hingga mengurangi ukuran molekul pati (Zhu, 2018).

Suhu gelatinisasi tepung sorgum termodifikasi enzimatis ini cenderung menurun seiring dengan semakin meningkatnya konsentrasi enzim $\alpha$-amilase. Suhu gelatinisasi tepung sorgum termodifikasi enzimatis ini berkisar antara $77,48-78,77^{\circ} \mathrm{C}$ dengan suhu gelatinisasi tepung sorgum alami sebesar $78,20^{\circ} \mathrm{C}$. Komponen amilosa dan amilopektin berpengaruh pada viskositas puncak dan suhu gelatinisasi pada pati tersebut sehingga kandungan amilosa yang tinggi menyebabkan viskositas puncak yang rendah dan kandungan amilopektin tinggi menghasilkan viskositas puncak yang tinggi (Murtiningrum et al., 2012). Sifat kimia amilosa dan amilopektin pada tepung sorgum dapat dilihat pada Tabel 3 .

Medikasari (2009) menyatakan bahwa kadar amilosa memengaruhi suhu gelatinisasi. Pembentukan ikatan hidrogen lebih mudah terjadi pada amilosa dan membentuk interaksi molekular yang kuat dengan air. Jika ditinjau dari kadar amilosanya, kadar amilosa tepung sorgum termodifikasi enzimatis ini mengalami penurunan seiring dengan semakin meningkatnya konsentrasi enzim $\alpha$-amilase yang digunakan. Dengan demikian, semakin tinggi konsentrasi enzim $\alpha$-amilase yang digunakan maka semakin rendah kadar amilosanya sehingga suhu gelatinisasi akan semakin rendah pula (Tan et al., 2009)

Viskositas puncak merupakan titik puncak kekentalan adonan saat proses pemanasan atau kondisi granula pati mencapai pengembangan maksimum sehingga selanjutnya pecah. Parameter ini digunakan sebagai tanda pati mudah matang saat dimasak dan menunjukkan adonan yang kuat yang terbentuk dari proses gelatinisasi selama pengolahan (Karmakar et al., 2014). Viskositas puncak tepung sorgum termodifikasi enzimatis ini cenderung menurun seiring dengan semakin meningkatnya konsentrasi $\alpha$-amilase, dimana viskositas puncak berkisar antara 856,19-1266,67 BU. Penurunan viskositas puncak tersebut terjadi karena adanya hidrolisis pada rantai amilosa dan amilopektin, sehingga kadarnya menurun. Amilopektin memiliki struktur 
bercabang dan membentuk double helix, serta berperan terhadap pengembangan pati. Saat pati dipanaskan ikatan hidrogen dapat terputus. Semakin banyak ikatan hidrogen yang putus maka air akan terserap masuk ke dalam granula pati dan mendorong amilosa yang memiliki rantai yang lebih pendek akan terdorong keluar dari granula pati, sehingga struktur dari granula pati menjadi lebih terbuka dan terisi oleh air yang menyebabkan pembengkakan dan viskositasnya meningkat. Oleh karena adanya hidrolisis pada rantai amilosa dan amilopektin, maka kemampuan pati untuk menyerap air dan mengembang semakin berkurang sehingga viskositas puncak semakin menurun. Kadar amilosa dan amilopektin tepung sorgum termodifikasi enzimatis mengalami penurunan seiring dengan meningkatnya konsentrasi $\alpha$-amilase yang digunakan, sehingga viskositas puncak akan semakin rendah pula.

Nilai viskositas puncak dapat digunakan untuk memperkirakan penggunaan tepung dalam jumlah kecil saat mencapai viskositas tertentu sehingga biaya produksi suatu produk pangan dapat ditekan. Menurut Karmakar et al. (2014), bahan baku dengan viskositas puncak $<500$ BU cocok untuk produk basah, bahan baku dengan viskositas puncak 500 1000 BU cocok untuk produk semi basah, dan bahan baku dengan viskositas puncak >1000 BU cocok untuk produk ekstrusi seperti kerupuk. Tabel 1 memperlihatkan bahwa tepung sorgum alami dan tepung sorgum termodifikasi enzimatis perlakuan 200 unit/g memiliki viskositas puncak masingmasing sebesar 1594,29 dan 1266,67 BU sehingga cocok untuk digunakan pada pembuatan produk ekstrusi, sedangkan tepung sorgum termodifikasi enzimatis perlakuan 400 dan 600 unit/g memiliki viskositas puncak masing-masing sebesar 998,57 dan 856,19 BU sehingga cocok untuk digunakan pada pembuatan produk semi basah atau intermediate moisture food (IMF).

Viskositas pasta panas dan breakdown merupakan parameter amilografi yang saling terkait. Vis- kositas pasta panas merupakan indeks kemudahan pemasakan dan merefleksikan kelemahan granula dalam mengembang, sedangkan breakdown menunjukkan stabilitas adonan selama proses pemasakan (Karmakar et al., 2014). Tepung sorgum termodifikasi enzimatis ini memiliki viskositas pasta panas berkisar antara 35-406 cP dengan viskositas pasta panas tepung sorgum alami sebesar $2184 \mathrm{cP}$, sedangkan breakdown tepung sorgum termodifikasi enzimatis ini berkisar antara 1763-2254 cP dengan breakdown tepung sorgum alami sebesar $1164 \mathrm{cP}$.

Parameter viskositas pasta panas dan breakdown mencirikan kestabilan pasta pati akibat pemanasan dan pengadukan dalam proses pengolahan (Beta dan Corke, 2011). Produk pangan yang menggunakan proses pengukusan akan memerlukan kestabilan pasta agar struktur produk stabil (Herawati, 2012). Tabel 1 memperlihatkan bahwa semakin tinggi konsentrasi enzim $\alpha$-amilase yang digunakan maka viskositas pasta panas dan breakdown tepung sorgum termodifikasi enzimatis semakin menurun. Kesimpulan yang diperoleh adalah bahwa semakin rendah viskositas pasta panas dan breakdown tepung sorgum termodifikasi enzimatis maka pasta yang terbentuk akan semakin stabil terhadap pemanasan.

Parameter selanjutnya adalah viskositas pasta dingin dan setback yang menunjukkan kecenderungan pati untuk mengalami retrogradasi (Marta, 2011). Selama proses pendinginan terjadi peningkatan viskositas pasta akibat adanya asosiasi antar molekul pati. Peningkatan tersebut menggambarkan kecenderungan retrogradasi pati (Lestari dan Koh, 2013). Tepung sorgum termodifikasi enzimatis ini memiliki viskositas pasta dingin berkisar antara 82554 cP dengan viskositas pasta dingin tepung sorgum alami sebesar $7321 \mathrm{cP}$, sedangkan setback tepung sorgum termodifikasi enzimatis berkisar antara 47-148 cP dengan setback tepung sorgum alami sebesar $5137 \mathrm{cP}$.

Tabel 2. Sifat fisik tepung sorgum termodifikasi enzimatis

\begin{tabular}{lcc}
\hline Perlakuan pada Sorgum & Derajat Putih $(\%)$ & Ukuran Granula $(\mu \mathrm{m})$ \\
\hline Tepung sorgum alami & $71,40 \pm 2,72$ & $17,36 \pm 2,53$ \\
Konsentrasi $\alpha$-amilase $200 \mathrm{U} / \mathrm{g}$ tepung & $74,28 \pm 0,95$ & $16,88 \pm 2,79$ \\
Konsentrasi $\alpha$-amilase $400 \mathrm{U} / \mathrm{g}$ tepung & $74,15 \pm 1,10$ & $15,12 \pm 3,15$ \\
Konsentrasi $\alpha$-amilase $600 \mathrm{U} / \mathrm{g}$ tepung & $73,93 \pm 0,17$ & $14,50 \pm 3,43$ \\
\hline
\end{tabular}

Keterangan: Nilai standar derajat putih $\mathrm{BaSO}_{4}=85,7 \%$

Tabel 3. Fraksi pati sorgum termodifikasi enzimatis

\begin{tabular}{lcccc}
\multicolumn{1}{c}{ Fraksi Pati (\%) } & Sorgum Alami & $\begin{array}{c}\text { Konsentrasi Enzim } \alpha- \\
\text { amilase } 200 \mathrm{U} / \mathrm{g} \text { tepung }\end{array}$ & $\begin{array}{c}\text { Konsentrasi Enzim } \alpha- \\
\text { amilase 400 U/g tepung }\end{array}$ & $\begin{array}{c}\text { Konsentrasi Enzim } \alpha- \\
\text { amilase 600 U/g tepung }\end{array}$ \\
\hline Amilopektin & $37,43 \pm 0,42$ & $32,64 \pm 1,36$ & $29,95 \pm 0,56$ & $25,54 \pm 0,69$ \\
Amilosa & $15,65 \pm 0,25$ & $15,77 \pm 1,39$ & $5,31 \pm 0,29$ & $14,64 \pm 0,68$ \\
\hline
\end{tabular}


Menurut Beta dan Corke (2011), setback dapat digunakan untuk mengukur kemampuan rekristalisasi selama pendinginan, berkaitan dengan retrogradasi dan penyusunan kembali molekul pati. Nilai setback yang rendah mengindikasikan kecenderungan retrogradasi dan sineresis yang rendah pula. Tabel 1 juga memperlihatkan bahwa semakin tinggi konsentrasi enzim $\alpha$-amilase yang digunakan maka viskositas pasta dingin dan setback tepung sorgum termodifikasi enzimatis semakin menurun, dengan demikian dapat disimpulkan bahwa semakin rendah viskositas pasta dingin dan setback tepung sorgum termodifikasi enzimatis kecenderungan retrogradasi akan semakin rendah pula. Hal ini menunjukkan sejalan dengan pernyataan Medikasari et al. (2009) bahwa tepung sorgum termodifikasi enzimatis ini memiliki potensi yang baik sebagai bahan baku untuk produk yang mengalami proses pemanasan pada suhu tinggi dan pengadukan mekanis. Rendahnya nilai setback tepung sorgum termodifikasi enzimatis ini juga berguna untuk produk-produk yang memiliki masalah mengenai sineresis atau staling sehingga dapat memperpanjang umur simpan dari produk-produk tersebut (Palabiyik et al., 2016).

\section{KESIMPULAN}

Modifikasi tepung sorgum dengan konsentrasi enzim $\alpha$-amilase sebesar 200 unit/g tepung menghasilkan tepung sorgum termodifikasi enzimatis dengan karakteristik yang lebih baik dibanding tepung sorgum alami, yaitu pola amilografi tipe A dengan suhu gelatinisasi $78,77^{\circ} \mathrm{C}$ dan viskositas puncak 1266,67 BU dengan kadar pati 48,41\%, kadar amilosa $15,77 \%$, dan kadar amilopektin $32,64 \%$, serta cocok untuk digunakan pada pembuatan produk ekstrusi.

\section{UCAPAN TERIMAKASIH}

Ucapan terimakasih tim peneliti sampaikan kepada DRPM-Unpad dan program HIBAH PUPT Kementerian Ristek dan Dikti 2016 sehingga penelitian ini dapat terlaksana dengan baik

\section{DAFTAR PUSTAKA}

Atma Y. 2018. Prinsip Analisis Komponen Pangan, Makro dan Mikro Nutrien. 38. CV. Budi Utama, Yogyakarta.

Beta T, Corke H. 2011. Noodle quality as related to sorghum starch properties. Cereal Chem 78: 417-420. DOI: 10.1094/CCHEM.2001.78.4.417.
Deka D, Sit N. 2016. Dual modification of taro starch by microwave and other heat moisture treatment. Int J Biol Macromol 92: 416-422. DOI: 10.1016/j.jjbiomac.2016.07.040.

Elkhalifa AEO, Bernhardt R. 2010. Influence of grain germination on functional properties of sorghum flour. Food Chem 121: 387-392. DOI: 10.1016/j. foodchem.2009.12.041.

Herawati H. 2012. Teknologi proses food ingredient dari tapioka termodifikasi. J Litbang Pertanian 31: 68-76.

Karmakar R, Ban DK, Ghosh U. 2014. Comparative study of native and modified starches isolated from conventional and nonconventional sources. Int Food Res J 21: 597-602.

Kaur B, Arifin F, Bhat R, Karim AA. 2012. Progress in starch modification in the last decade. Food Hydrocolloid 26: 398-404. DOI: 10.1016/j.food hyd.2011.02.016.

Kulamarva AG, Sosle VR, Raghavan GSV. 2009. Nutritional and rheological properties of sorghum. Int J Food Prop 12: 55-69. DOI: 10.1080/ 10942910802252148.

Lestari P, Koh H. 2013. Evaluasi kandungan protein dan sifat pasta beras japonica dengan marka DNA. Berita Biologi 12: 141-152.

Medikasari, S. Nurdjanah, N. Yuliana, Lintang N. 2009. Sifat amilografi pasta pati sukun termodifikasi menggunakan sodium Tripolifosfat. J Teknol Industri Hasil Pertanian 14: 173-177.

Murtiningrum, Lisangan MM, Edoway Y. 2012. Pengaruh preparasi ubi jalar (Ipomoe batatas) sebagai bahan pengental terhadap komposisi kimia dan sifat organoleptik saus buah merah (Pandanus Conoideus L). Agrointek 6: 1-7.

Mokrane $\mathrm{H}$, Amoura $\mathrm{H}$, Bensemra NB, Courtin CM, Delcour JA, Nadjemi B. 2010. Assesment of Algerian sorghum protein quality (Sorghum bicolor (L.) Moench) using amino acid analysis and in vitro pepsin digestibility. Food Chem 121: 719-723. DOI: 10.1016/j.foodchem.2010.0 1.020.

Neelam K, Vijay S, Lalit S. 2012. Various techniques for the modification of starch and the applications of its derivatives. Int Res J Pharm 3: 2537.

Palabiyik I, Yildiz O, Toker OS, Cavis M, Ceylan MM, Yurt B. 2016. Investigating the addition of enzymes in gluten-free flours-The effect on pasting and textural properties LWT-Food Sci Technol 69: 633-641. DOI: 10.1016/j.Iwt.2016. 01.019 . 
Suarni. 2016. Peranan sifat fisikokimia sorgum dalam diversifikasi pangan dan industri serta pros pek pengembangannya. $\mathrm{J}$ Litbang Pertanian 35: 99-110. DOI: 10.21082/jp3.35n3.2016.p99110.

Tan HZ, Li ZG, Tan B. 2009. Starch noodles: History, classification, materials, processing, structure, nutrition, quality evaluating, and improving. Food Res Int 42: 551-576. DOI: 10.1016/j.food res.2009.02.015.
Yan H, Zhengbiao GU. 2010. Morphology of modified starched prepared by different methods. Food Res Int 43: 767-772. DOI: 10.1016/j.food res.2009.11.013.

Zhu F. 2018. Relationships between amylopectin internal molecular structure and physicochemical properties of starch. Trends Food Sci Technol 78: 234-242. DOI: 10.1016/j.tifs.2018.05.024. 